\title{
Maahan muuttaneiden kokonaisvaltainen kotoutuminen edellyttää myös poliittista osallisuutta
}

JOSEFINA SIPINEN

Yksi keskeisistä kysymyksistä muuttoliikkeen sävyttämässä maailmassa on, miten valtiot ja kansakunnat kykenevät integroimaan eli kotouttamaan uudet tulijat ja heidän jälkeläisensä osaksi yhteiskuntaa. Kotoutuminen tapahtuu lukuisilla yhteiskunnan eri osa-alueilla, kuten työmarkkinoilla, mutta myös politiikassa. Maahan muuttaneiden poliittinen kiinnittyminen uudessa kotimaassaan - mukaan lukien kyky ymmärtää ja vaikuttaa poliittisiin prosesseihin sekä kiinnostus seurata yhteiskunnallisia asioita - edistää heidän kotoutumistaan paitsi yksilöinä myös ryhminä.

Ulkomaalaistaustaisten osuus väestöstä alkoi Suomessa kasvaa 1990-luvun alusta lähtien. Nyt lähes joka kymmenes Suomessa asuva on syntynyt muualla kuin Suomessa tai vähintäänkin hänen vanhempansa ovat muuttaneet Suomeen toisesta maasta. Pääkaupunkiseudulla ulkomaalaistaustaisten osuus väestöstä on selvästi muuta maata korkeampi: esimerkiksi Vantaalla jo joka viides kuntalainen on ulkomaalaistaustainen. (Tilastokeskus 2021.)

Poliittisten oikeuksien laajentamista muille kuin maan kansalaisille on perusteltu lukuisin eri syin. Yksi yleisimmistä liittyy jo Yhdysvaltojen itsenäistymishistoriassa suuren merkityksen saaneeseen ajatukseen siitä, että "verotus ilman edustusta on tyranniaa" (ks. esim. Smith 1998, 23). Ketään ei siis tulisi velvoittaa maksamaan veroja ilman, että he pääsevät vaikuttamaan verojen suuruuteen tai niiden käyttöön.

On myös niin, että toimivan demokratian näkökulmasta koko yhteiskunnan kannalta parasta politiikkaa tehdään silloin, kun mahdollisimman monien väestöryhmien ääni on edustettuna päätöksenteossa, eikä mikään ryhmä jää poliittiseen paitsioon. Tällöin päätöksenteossa on mahdollisuus kuulla ja huomioida mahdollisimman monia erilaisia näkökulmia. (Mansbridge 1999; Phillips 1995.) Lisäksi voidaan perustellusti olettaa, että ulkomaalaistaustaisen väestön tasavertaiset mahdollisuudet päästä mukaan yhteiskunnalliseen päätöksentekoon vahvistavat heidän kokemuksiaan osallisuudesta ja suomalaiseen yhteiskuntaan kuulumisesta.

Erityisesti Suomessa syntyneille ulkomaalaistaustaisille - eli niin kutsutulle seuraavalle sukupolvelle - kokemukset osallistumisen esteistä ja syrjinnästä voivat heijastua kielteisinä käsityksinä koko maata ja sen poliittista järjestelmää kohtaan. Päinvastoin kuin vanhempansa seuraava sukupolvi on syntynyt ja kasvanut saman poliittisen järjestelmän piirissä, ja heidän odotuksensa sitä kohtaan ovat siten samat kuin valtaväestöllä. Onkin huolestuttavaa, mikäli he kokevat etnisen taustansa olevan este täysimääräiselle poliittiselle osallistumiselle. Etnisten vähemmistöjen ja/tai maahanmuuttotaustaisten mukanaolo poliittisessa päätöksenteossa viestii tasa-arvoisesta ja moniäänisestä yhteiskunnasta, jossa jokaisella on yhtäläinen mahdollisuus vaikuttaa yhteisiin asioihin syntyperästään riippumatta.

Sulkekaa hetkeksi silmänne ja pohtikaa, millainen mielikuva teille tulee sanasta "päättäjä". Miltä tämä henkilö näyttää? Miltä hän kuulostaa? Vallankäyttäjien moninaisuudella on symbolista merkitystä. Sillä, että päättäjämme eivät ole vain valkoihoisia, keski-ikäisiä ja vähintään 
ylempään keskiluokkaan kuuluvia miehiä, on valtava merkitys sille, kuka päättäjän tehtävään rohkenee hakeutua (ks. esim. Bobo ja Gilliam 1990; Stokes-Brown ja Dolan 2010).

Etniset vähemmistöt, naiset ja nuoret ovat perinteisesti olleet aliedustettuina yhteiskunnallisen vallan käyttäjien joukossa. Naisten edustus vaalien ehdokaslistoilla ja päättäjinä on kuitenkin merkittävästi kohentunut Suomessa viimeisten vuosikymmenten aikana (Pikkala 2020). Tämä kehitys ei ole kuitenkaan tapahtunut itsestään, vaan se on vaatinut päämäärätietoisia askelia. Nyt kun Suomen väestö muuttuu vuosi vuodelta yhä moninaisemmaksi, uusien etnisten vähemmistöjen poliittinen edustus nousee pikavauhtia tärkeäksi yhteiskunnalliseksi kysymykseksi.

Joku teistä saattaa nyt pohtia mielessään, tarvitseeko päättäjien itse edustaa vähemmistöä kyetäkseen huomioimaan näiden edut päätöksenteossa. Poliittisen edustuksellisuuden tarkasteluissa on perinteisesti tehty jaottelu kahteen eri edustuskäsitykseen. Niin kutsutulla deskriptiivisellä eli peilikuvaedustuksella viitataan näkemykseen, jonka mukaan edustettavan - siis tilanteesta riippuen esimerkiksi kansalaisen tai kuntalaisen - näkemykset ja intressit tulevat parhaiten edustetuiksi silloin, kun hänen poliittinen edustajansa on ominaisuuksiltaan mahdollisimman samankaltainen edustettavan kanssa. Ajatus on, että esimerkiksi samaa sukupuolta oleva tai samaan ikäryhmään, yhteiskuntaluokkaan tai etniseen ryhmään kuuluva edustaja kykenee parhaiten edistämään äänestäjälle tärkeitä asiakysymyksiä ja arvoja päätöksenteossa. (Mansbridge 1999; Phillips 1995; Pitkin 1967.)

Niin kutsutun substantiivisen edustuskäsityksen mukaan edustaja puolestaan profiloituu tietyille äänestäjäryhmille tärkeiden asiakysymysten ajajana huolimatta siitä, missä määrin hän jakaa samanlaisen taustan edustettaviensa kanssa. Tämä niin kutsuttu asiakysymysedustus on olennaista myös deskriptiivisessä edustuksessa, jossa kuitenkin lähdetään siitä oletuksesta, että arvot ja mielipiteet tulevat edustetuiksi sitä kautta, että edustaja on itse lähtöisin edustettavien kanssa samasta ryhmästä ja tuntee sen olosuhteet. (Mansbridge 1999; Phillips 1995; Pitkin 1967.)

Väestössä esiintyvät mielipiteet siis voisivat teoriassa tulla edustetuiksi ilman, että edustajien henkilökohtaiset ominaisuudet vastaavat peilikuvanomaisesti edustettavan joukon ominaisuuksia, kuten etnistä taustaa. Käytännössä edustajien taustoilla on kuitenkin vaikutusta politiikan sisältöön. Lukuisissa kansainvälisissä tutkimuksissa on havaittu, että vähemmistöihin itse kuuluvat edustajat nostavat esiin vähemmistöille keskeisiä kysymyksiä muita edustajia enemmän (ks. esim. Butler \& Broockman 2011; Bird 2011). Tästä syystä voidaan lähteä olettamasta, että monista eri taustoista tulevat päättäjät takaavat sen, että eri väestöryhmien ääni todella on läsnä päätöksenteossa.

Suomessa tämä näkökulma, jonka mukaan poliittiset oikeudet edistävät yhteiskuntaan kiinnittymistä, on huomioitu. Suomi on muiden Pohjoismaiden tavoin myöntänyt maassa asuville ulkomaiden kansalaisille oikeuden äänestää ja asettua ehdolle paikallisvaaleissa, mutta rajannut samat oikeudet eduskunta- ja presidentinvaaleissa ainoastaan kansalaisille. Presidentinvaaleissa ehdolle saa asettua ainoastaan syntyperäinen Suomen kansalainen.

Vaikka Suomen poliittinen järjestelmä takaa ulkomaalaistaustaisille verrattain hyvät mahdollisuudet poliittiseen osallistumiseen kuntatasolla, etnisiin ja maahanmuuttotaustaisiin vähemmistöihin kuuluvien äänestysaktiivisuus sekä edustus ehdokaslistoilla ja kunnanvaltuustoissa on yhä hyvin pieni suhteessa heidän osuuteensa äänioikeutetuista (Sipinen 2021, 25). 
On tosin syytä huomata, että eri etnisten ryhmien osallistumisaktiivisuus ja edustuksen taso vaihtelevat, mitä selittävät moninaiset taustamaahan, Suomeen muuton syihin ja ryhmien kotoutumiseen liittyvät tekijät. Poliittiset osallistumismahdollisuudet ovat riippuvaisia paitsi yksilön ja ryhmän identiteetistä, sosiaalisista verkostoista ja tiedollisista resursseista myös siitä, kuinka vastaanottavaisia suomalainen yhteiskunta ja sen poliittinen järjestelmä eri ryhmien kohdalla ovat. (Bird ym. 2011; Sipinen 2021; Wass ja Weide 2015.) On todettava, etteivät kaikki tulijat saa suomalaisilta yhtä lämmintä ja varauksetonta vastaanottoa. Tutkimukset osoittavat, kuinka syrjintää tapahtuu niin arkipäiväisissä kohtaamisissa kuin myös esimerkiksi työelämässä ja asuntomarkkinoilla (Ahmad 2020; Jaakkola 2005; Rask ym. 2020).

Taannoisessa konferenssissa eräs tutkija kuvaili mielestäni osuvasti kotoutumista "moniulotteiseksi himmeliksi". Kotoutuminen on laaja kokonaisuus ja sen eri osa-alueet ovat tiiviissä vuorovaikutuksessa keskenään. Siispä kun yhdelle puolelle tökkäät, koko himmeli väreilee. Tutkijat ovat eritelleet kotoutumisen osa-alueita eri tavoin. Esimerkiksi vastaväittäjäni dosentti Pasi Saukkonen (2020) on viime vuonna julkaistussa kirjassaan hyödyntänyt saksalaisen muuttoliiketutkija Friedrich Heckmannin (2005) jaottelua. Heckmannin mukaan kotoutuminen voidaan jakaa neljään ulottuvuuteen: kulttuuriseen, vuorovaikutukselliseen, identifioivaan ja rakenteelliseen.

Kulttuurisella kotoutumisella viitataan erilaisiin tiedollisiin ja käyttäytymisen sekä arvojen ja asenteiden muutoksiin. Se tarkoittaa paikallisten tapojen, normien ja pelisääntöjen ymmärtämistä ja omaksumista niin, että arki uudessa ympäristössä on sujuvaa ja kulttuurien väliset ristiriidat ovat harvinaisia. Esimerkiksi paikallisen kielen oppiminen on keskeinen osa kulttuurista kotoutumista. Vuorovaikutuksellisessa kotoutumisessa keskeisiksi muodostuvat sosiaaliset, eri väestöryhmiin muodostuvat siteet. Yleisesti ajatellaan, että mitä monipuolisemmiksi tulijoiden verkostot muodostuvat ja mitä tiiviimmin he ovat vuorovaikutuksessa valtaväestön kanssa, sitä paremmat edellytykset heillä on toimia yhteiskunnassa. Vuorovaikutus myös lisää eri väestöryhmien välistä luottamusta. (Heckmann 2005, 15-18; Saukkonen 2020, 19-20.)

Identifioivassa kotoutumisessa huomio kiinnittyy maahan muuttaneiden identiteetteihin. Kotoutumista tällä osa-alueella tapahtuu silloin, kun maahan muuttanut alkaa tuntea itsensä uuden kotimaansa täysivaltaiseksi ja yhdenvertaiseksi jäseneksi. Tällaisten samaistumisen tunteiden syntyminen kuitenkin useimmiten edellyttää, että myös muut hyväksyvät tulijan osaksi yhteiskuntaa. Rakenteellisessa kotoutumisessa puolestaan on kyse maahan muuttaneiden asemasta yhteiskunnan taloudellis-sosiaalisissa rakenteissa sekä siitä, miten yhdenvertaisuus niissä toteutuu. (Heckmann 2005, 15-18; Saukkonen 2020, 19-20.) Miten maahan muuttaneet sijoittuvat esimerkiksi työmarkkinoille ja koulutusjärjestelmiin? Entä miten he pääsevät osaksi maan terveydenhuoltoa ja muita julkisia palveluita? Myös poliittinen osallisuus ja kiinnittyminen poliittiseen järjestelmään voidaan lukea osaksi rakenteellista kotoutumista.

Palatakseni ajatukseen kotoutumisesta "himmelinä" ei siis voida ajatella, että kotoutumisen eri ulottuvuudet olisivat toisistaan erillään. Edistysaskeleet yhdellä kotoutumisen ulottuvuudella voivat vaikuttaa myönteisesti myös toisella ja päinvastoin (Valaste ja Wass 2019). Yksilöiden ja ryhmien kotoutumista ei myöskään pitäisi arvioida tarkastelemalla puhtaasti vain yhtä kotoutumisen osa-aluetta, kuten esimerkiksi kiinnittymistä työmarkkinoille. Suomeen muuttaneiden poliittinen kiinnittyminen ei siis ole kotoutumisen tulos vaan osa prosessia, ja poliittinen kiinnittyminen voi edistää yksilöiden ja ryhmien kotoutumista myös muilla yhteiskunnan osaalueilla. 
Viime vuosina Suomeen muuttaneiden kotoutumisesta on saatu yhä enemmän tutkittua tietoa. Tietämyksemme uusien tulijoiden poliittisesta kiinnittymisestä on kuitenkin toistaiseksi erittäin niukkaa (ks. kuitenkin esim. Pirkkalainen ym. 2016; Sipinen 2019; Valaste ja Wass 2019; Wass ja Weide 2015). Vaikka lukuisissa muissa maissa laajamittaisen maahanmuuton historia on huomattavasti pidempi kuin Suomessa, maasta- ja maahanmuuttajien poliittisen kiinnittymisen tutkimus on alitutkittu alue myös kansainvälisesti. Tämä johtuu esimerkiksi siitä, että joissain Länsi-Euroopan maissa siirtotyöläisten odotettiin pitkään palaavan takaisin lähtömaahansa sen sijaan, että he olisivat jääneet maahan pysyvästi (ks. Saksan osalta esim. Chin 2007). Poliittisten oikeuksien laajentaminen muille kuin maan kansalaisille ei siten ainakaan aluksi tuntunut ajankohtaiselta. Tilannekuva on sittemmin merkittävästi muuttunut, ja monissa maissa on herätty seurauksiin, joita vähemmistöjen poliittinen marginalisoituminen on aiheuttanut (ks. esim. Dancygier 2010).

Tällä väitöstutkimuksella olen halunnut vastata maahan muuttaneiden poliittista kiinnittymistä koskevaan tiedontarpeeseen. Vaikka kansainvälisestä tutkimuksesta voidaan vetää joitain oletuksia myös Suomen osalta, vaalijärjestelmät eri vaaleissa ja eri maissa ovat keskenään hyvin erilaisia, ja luovat siten erilaisia mahdollisuuksia vähemmistöryhmien poliittiselle kiinnittymiselle. Jos haluamme selvittää, millaiset seikat edistävät tai heikentävät ulkomaalaistaustaisen poliittista osallisuutta Suomessa, meidän on tarkasteltava ilmiötä myös kansallisessa kontekstissa.

Puolueilla on keskeinen rooli siinä, missä määrin eri väestöryhmien edustus poliittisissa päätöksentekoelimissä toteutuu, sillä puolueet vastaavat vaalien ehdokasasettelusta ja valitsevat sen joukon, jonka keskuudesta äänestäjät valitsevat edustajansa vaaleissa. Vuoden 2017 kuntavaaleissa yhteensä 97,6 prosenttia ehdokkaista oli ehdolla puolueiden listoilla, mikä korostaa puolueiden merkittävää asemaa yhteiskunnallisina portinvartijoina. Mitä aktiivisemmin puolueet onnistuvat integroimaan etnisiin ja maahanmuuttotaustaisiin vähemmistöihin kuuluvia yksilöitä ja ryhmiä osaksi toimintaansa, sitä paremmat todennäköisyydet uusilla tulijoilla on löytää paikkansa Suomen poliittisessa järjestelmässä. Mitä paremmin uudet tulijat puolestaan pääsevät osaksi poliittista järjestelmää, sitä turvatumpi sen legitimiteetti on pitkällä tähtäimellä katsottuna.

Korona-aika on osoittanut, kuinka valtaväestölle tutuksi käynyt viranomaisviestintä tavoittaa heikosti vieraskieliset vähemmistöt (ks. esim. Vantaan Sanomat 19.3.2020). Esimerkiksi oikeusministeriössä tehdään monenlaista työtä vaaliviestinnän parissa ja panostetaan enenevässä määrin myös monikieliseen viestintään, kuten tiedotetaan kotiin lähetettävällä kirjeellä äänioikeudesta niitä, joille äänestäminen on ensimmäistä kertaa mahdollista kyseisissä vaaleissa. Vieraskielisen väestön näkökulmasta tärkeimpiä tietolähteitä ovat kuitenkin todennäköisesti omat verkostot. Puolueiden näkökulmasta ehdokkaat, jotka kykenevät kampanjoimaan eri kielillä, ovat keskeinen voimavara vieraskielisten äänestäjien tavoittamisessa.

Loppuun todettakoon, että ehdoton toiveeni on nostaa ulkomaalaistaustaisten poliittinen kiinnittyminen tiiviimmin osaksi kotoutumisesta käytävää keskustelua myös Suomessa ja nähdä tulevien vuosien aikana lisää tutkimusta tästä aihepiiristä. Kesäkuisissa kuntavaaleissa oli jälleen ehdolla maahanmuuttotaustaisia, ja jäänkin seuraamaan mielenkiinnolla, miten maahan muuttaneet näkyvät Suomen politiikassa jatkossa. 
Väitöskirja "Recruitment of Immigrant-origin Candidates in Finnish Municipal Elections" tarkastettiin Tampereen yliopistossa 23.4.2021. Vastaväittäjänä toimi erikoistutkija, dosentti Pasi Saukkonen Helsingin kaupunginkanslian kaupunkitutkimus ja -tilastot -yksiköstä ja kustoksena tenure track -professori Elina Kestilä-Kekkonen Tampereen yliopistosta.

\section{LÄHTEET}

Ahmad, Akhlaq. 2020. When the Name Matters: An Experimental Investigation of Ethnic Discrimination in the Finnish Labor Market. Sociological Inquiry 90:3, 468-496. https://doi.org/10.1111/soin.12276

Bird, Karen. 2011. Patterns of Substantive Representation among Visible Minority MPs: Evidence from Canada's House of Commons. Teoksessa Karen Bird, Thomas Saalfeld ja Andreas M. Wüst (toim.), The Political Representation of Immigrants and Minorities: Voters, Parties and Parliaments in Liberal Democracies. Lontoo: Routledge, 207-229.

Bird, Karen, Saalfeld, Thomas ja Wüst, Andreas. M. 2011. Ethnic Diversity, Political Participation and Representation: A Theoretical Framework. Teoksessa Karen Bird, Thomas Saalfeld ja Andreas M. Wüst (toim.) The Political Representation of Immigrants and Minorities: Voters, Parties and Parliaments in Liberal Democracies. Lontoo: Routledge, 1-21.

Bobo, Lawrence ja Gilliam, Franklin D. 1990. Race, Sociopolitical Participation, and Black Empowerment. American Political Science Review 84:2, 377-393. doi:10.2307/1963525Butler, Daniel M. ja Broockman, David E. 2011. Do Politicians Racially Discriminate against Constituents? A Field Experiment on State Legislators. American Journal of Political Science 55:3, 463-477. https://www. jstor.org/stable/23024931

Chin, Rita. 2007. The Guest Worker Question in Postwar Germany. New York: Cambridge University Press.

Dancygier, Rafaela. 2010. Immigration and Conflict in Europe. New York: Cambridge University Press.

Heckmann, Friedrich. 2005. Integration and Integration Policies. Bamberg: European Forum for Migration Studies.

Jaakkola, Magdalena. 2005. Suomalaisten suhtautuminen maahanmuuttajiin vuosina 1987-2003. Työpoliittinen tutkimus 286. Helsinki: Työministeriö, Opetusministeriö.

Mansbridge, Jane. 1999. Should Blacks Represent Blacks and Women Represent Women? A Contingent 'Yes.' Journal of Politics 61:3, 628-657. https://doi.org/10.2307/2647821

Phillips, Anne. 1995. The Politics of Presence. Oxford: Oxford University Press.

Pikkala, Sari. 2020. Naiset eduskuntavaaleissa ja sukupuolen merkitys äänestämisessä. Teoksessa Sami Borg, Elina Kestilä-Kekkonen ja Hanna Wass (toim.), Politiikan ilmastonmuutos. Eduskuntavaalitutkimus 2019. Helsinki: Oikeusministeriö, 80-102.

Pirkkalainen, Päivi, Wass, Hanna ja Weide, Marjukka. 2016. Suomen somalit osallistuvina kansalaisina. Yhteiskuntapolitiikka 81:1, 69-77.

Pitkin, Hanna F. 1967. The Concept of Representation. Berkeley: University of California Press.

Rask, Shadia, Castaneda, Anu ja Seppänen, Anna. 2020. Syrjintä- ja väkivaltakokemukset. Teoksessa Hannamaria Kuusio, Anna Seppänen, Satu Jokela, Laura Somersalo ja Eero Lilja (toim.), 
Ulkomaalaistaustaisten terveys ja hyvinvointi Suomessa - FinMonik-tutkimus 2018-2019. Helsinki: Terveyden ja hyvinvoinnin laitos, 91-96.

Saukkonen, Pasi. 2020. Suomi omaksi kodiksi. Kotouttamispolitiikka ja sen kehittämismahdollisuudet. Helsinki: Gaudeamus.

Smith, Daniel A. 1998. Tax Crusaders and the Politics of Direct Democracy. New York: Routledge.

Sipinen, Josefina. 2019. Ulkomaalaistaustaiset ehdokkaat kuntavaaleissa 2017. Teoksessa Villiina Kazi, Anne Alitolppa-Niitamo ja Antti Kaihovaara (toim.), Kotoutumisen kokonaiskatsaus 2019. Tutkimusartikkeleita kotoutumisesta. Helsinki: Työ- ja elinkeinoministeriö, 181-192.

Sipinen, Josefina. 2021. Recruitment of Immigrant-origin Candidates in Finnish Municipal Elections. Tampere: Tampereen yliopisto.

Stokes-Brown, Atiya Kai ja Dolan, Kathleen (2010). Race, Gender, and Symbolic Representation: African American Female Candidates as Mobilizing Agents. Journal of Elections, Public Opinion and Parties 20:4, 473-494. https://doi.org/10.1080/17457289.2010.511806

Tilastokeskus. 2021. Maahanmuuttajataustaisten määrät ja osuudet alueittain, 1990-2019. https://pxnet2.stat.fi/PXWeb/pxweb/fi/Maahanmuuttajat_ja_kotoutuminen/Maahanmuuttajat_ja_kotoutuminen_Maahanmuuttajat_ja_kotoutuminen/maakoto_pxt_11vu.px/. Viitattu 31.5.2021.

Vantaan Sanomat 19.3.2020. Vantaa viestii Wilman kautta kahdeksalla kielellä - Valmiuslaki arabiaksi -videosta tuli hetkessä hitti. https://www.vantaansanomat.fi/paikalliset/1493559. Viitattu 28.5.2021.

Valaste, Maria ja Wass, Hanna. 2019. Poliittinen osallistuminen osana kokonaisvaltaista kotoutumista. Teoksessa Villiina Kazi, Anne Alitolppa-Niitamo ja Antti Kaihovaara (toim.), Kotoutumisen kokonaiskatsaus 2019. Tutkimusartikkeleita kotoutumisesta. Helsinki: Työ- ja elinkeinoministeriö, 193-205.

Wass, Hanna ja Weide, Marjukka. 2015. Äänestäminen osana poliittista kansalaisuutta: Maahanmuuttotaustaisten äänioikeutettujen osallistuminen vuoden 2012 kunnallisvaaleissa. Helsinki: Oikeusministeriö.

\section{KIRJOITTAJATIEDOT}

\section{JOSEFINA SIPINEN}

YTT, FM, postdoc-tutkija

Politiikan tutkimus

Johtamisen ja talouden tiedekunta

Tampereen yliopisto

josefina.sipinen@tuni.fi 